\title{
Spiritual AND Material Rewards on the Christian-Muslim Frontier: Norman Crusaders in the Valley of the Ebro in the First Half of the Twelfth Century ${ }^{1}$
}

\author{
LuCAS VilLEgAs-AristizÁBAL ${ }^{2}$ \\ Queen's University: Bader International Study Centre \\ United Kingdom
}

\begin{abstract}
This article explores the involvement of the Norman nobility in the wars between Christians and Muslims in the Ebro Valley in the first half of the $12^{\text {th }}$ Century. The work recognises how the participation of this particular ethno-cultural group in the peninsula was renovated to a certain degree by the deeds and religious transformation that took place as a result of the preaching and success of the First Crusade. Furthermore, by exploring the careers of Rotrou of Perche, Robert Burdet and Walter Guidvilla this piece demonstrates how their religiosity as well as the filial relations and traditional desire for wealth that characterise this group of warriors, made the Iberian theatre of conflict so attractive at this particular period. Also, this article, tries to show how their Iberians lay and clerical coreligionists perceived the usefulness of these Norman contingents in their conflict with the Almoravids.
\end{abstract}

\section{Key words}

Crusade; Reconquista; Normans; fiefs; Holy War; Aragon; Tarragona.

\section{Resumen}

Este artículo explora la contribución de la nobleza normanda (Francesa) en las guerras entre cristianos y musulmanes en el valle del Ebro en la primera mitad del siglo XII. El trabajo reconoce como la participación de este particular grupo étnico-cultural en la península fue renovada hasta cierto punto por los hechos y la transformación que tuvo lugar a raíz de la predicación y el triunfo de la primera cruzada. Además, al explorar carreras de Rotrou de Perche, Roberto Burdet y de Gualter Guidvilla, esta pieza demuestra como su religiosidad al mismo tiempo que sus relaciones filiales y la tradicional codicia que caracterizó a estos guerreros, hizo que el teatro de conflicto peninsular fuese tan atractivo para ellos en este periodo. También, este artículo intenta mostrar como sus correligionarios ibéricos laicos y religiosos percibían la utilidad de estos contingentes normandos en sus conflictos contra los Almorávides.

\footnotetext{
1 I would like to offer my gratitude for their help and for allowing me access to their resources to the Institute of Historical Research (London), 南山大学図書館/University of Nanzan Library (Nagoya, Japan), the Biblioteca Pública de Tarragona, Archivo de la Corona de Aragón (Barcelona), Archivo General de Navarra (Pamplona), el Archivo Nacional de España (Madrid), the ecclesiastical and municipal archives of Vic, Barcelona, Tarragona, Zaragoza, Pamplona, Tudela, Calahorra and Huesca.

I would also like to show my gratitude for the help provided for the completion of this paper to my partner Naho Shiba, and my friends Francisco García Fitz, Chris Lewis and Connor James Patrick Kelly.

2 Correo electrónico: 1_villegas@bisc.queensu.ac.uk.
} 


\section{Palabras clave}

Cruzada; Reconquista; Normandos; feudos; Guerra Santa; Aragón; Tarragona.

\section{Résumé}

Cet article examine la participation de la noblesse normande aux guerres entre chrétiens et musulmans dans la vallée de l'Ebre pendant la première moitié du XIIe siècle. On y démontre que l'implication de ce groupe ethnoculturel dans la Péninsule a été relancée dans une certaine mesure par les événements et les changements provoqués par la prédication de la première croisade et son succès. De plus, l'étude des carrières de Rotrou du Perche, de Robert Burdet et de Walter Guidvilla, révèle que leur religiosité ainsi que les relations filiales et la cupidité propre à ces guerriers eurent pour conséquence de rendre attractif à leur yeux leur participation active au conflit péninsulaire à cette époque. De plus, cet article tente de montrer comment leurs coreligionnaires ibériques, tant laïcs que clercs, ont perçu l'utilité de ces contingents normands dans leur conflit avec les Almoravides.

\section{Mots clés}

Croisade; Reconquista; Normands; fiefs; Guerre Sainte; Aragon; Tarragona.

The aftermath of the First Crusade to the Holy Land seems to have reinvigorated the involvement of trans-Pyrenean contingents in the wars against Islamic Iberia. ${ }^{3}$ The success of the crusading appeal at Clermont Ferrand by Pope Urban II had bolstered the involvement of the European nobility in the wars against the enemies of the faith with promises of remission of sins and a combination of the traditions of pilgrimage with those of Holy War that had been forming for the previous centuries. ${ }^{4}$ The Normans on the other hand had been involved in the wars against the enemies of the Church since at least the mid-eleventh century when they became involved in the capture of Islamic Sicily and the ephemeral conquest of Barbastro. ${ }^{5}$ However, with the successes achieved

3 Francisco García Fitz, "La Reconquista: Un estado de la cuestión”, Clio \& Crimen, 6 (2009), pp. 142-215.

4 Joseph F. O'Callaghan, Reconquest and Crusade in Medieval Spain, ed. Penn, Philadelphia, 2003, pp. 1-22; Norman Housley, Contesting the Crusades, ed. Blackwell, Oxford, 2006, pp. 90-91; Thomas AsBridge, The Creation of the Principality of Antioch, ed. Boydell Press, Woodbridge, 2000.

5 Pierre Boissonade, "Cluny, la papauté et la première grande croisade internationale contre les sarrasins d'Espagne: Barbastro (1064-1065)", Revue des questions historiques, 60 (1932), pp. 257-301; Étienne DELARUELle, "The Crusading Idea in the Cluniac Literature of the Eleventh Century", Cluniac Monasticism in the Central Middle Ages, Noreen Hunt (ed.), ed. Macmillan, London, 1971, pp. 209-210; Carl Erdmann, The Origins of the Idea of Crusade, Marshall W. BALDwIN (trans.), ed. Princeton University Press, Princeton, 1977, pp. 288-289; Vicente CANTARINO, “The Spanish Reconquest: A Cluniac Holy War against Islam?" Islam and the Medieval West, Khalil I. SemaAn (ed.), ed. Albany, 1980, pp. 88-89; O'Callaghan, Reconquest and Crusade, pp. 1-22; Carlos LALIENA CoRBERA, "Larga stipendia et optima prædia: Les nobles francos en Aragon au servisse d'Alphonse le Batailleur", Annales du Midi, 229 (2000), pp. 149-169; Jonathan Riley-Smith, The Crusades, A Short History, ed. Yale University Press, London, 2001, pp. 3-7; Marcus BULL, Knightly Piety and the Lay Response to the First Crusade: The Limousin and Gascony, c. 970-c. 1130, ed. Oxford University Press, Oxford, 1993, pp. 33-39; Marcus BULL, "Origins", The Oxford History of the Crusades, Jonathan RILEY-SMITH (ed.), ed. Oxford University Press, Oxford, 1999, pp. 15-34; Herbert E. J. Cowdrey, Pope Gregory VII 10731085, ed. Oxford University Press, Oxford, 1998, p. 468; Paul OldField y Kathryn Hurlock, "Introduction", Crusading and Pilgrimage in the Norman World, Paul Oldfield (ed.) y Kathryn Hurlock (ed.), ed. Boydell, Woodbridge, 2015, pp. 1-10; Lucas Villegas-AristiZÁBAL, "Norman and Anglo-Norman Interventions in the Iberian Wars of Reconquest before and after the First Crusade", Crusading and Pilgrimage in the Norman World, Paul Oldfield (ed.) y Kathryn Hurlock (ed.), ed. Boydell, Woodbridge, 2015, pp. 103-121. 
by Robert Carthuse and Bohemond of Taranto in the Levant, the frontier seems to have attracted a new wave of enthusiasm from this group who historically had not been shy from adventurous desire for land and plunder from Scotland to Antioch, but now were being promised spiritual rewards for their endeavours as well. Bohemond of Taranto and his conquest of the city of Antioch during the First Crusade showed Normans the possibilities for material and spiritual rewards that could be achieved under this new type of warring pilgrimage. ${ }^{6}$ On the other hand, the gradual sacralisation of the Iberian theatre would allow those whose resources were more limited to have access to some of these rewards. In the early decades of the twelfth century, there were a few Norman crusaders who played an important role in the wars of reconquest in Navarre, Aragon and Catalonia. They were Rotrou of Perche and his followers: Sylvester of Saint-Calais, Reginald of Bailleul, Roger of Falais, Walter de Guidvilla, Geoffrey of Argentan, Algrin of Sechrouvre, Robert of Judas and Robert Burdet. ${ }^{7}$ Of these, the most significant in the documentary and narrative sources are Rotrou and Robert Burdet. Rotrou's contribution in the Iberian Reconquista soon after the capture of Zaragoza (1118) allowed him to acquire a lordship in Tudela and to be involved in different crusading themed campaigns against the Almoravids. Robert Burdet is remembered for his involvement in New Catalonia where he managed to gain the title of prince under the suzerainty of the church of the spiritually important city of Tarragona. Sylvester and Reginald, on the other hand, did not seem to acquire much with regards to lands preferring to return home, according to Orderic Vitalis, which illustrates the penitential aspects of their involvement. ${ }^{8}$ Some of the others such as Walter de Guidvilla seem to have acquired some lands displaying that as in the Holy Land the crusaders were equally eager to embark on this kind of expedition for enrichment of the body as well as the soul..$^{9}$ It is, therefore, the purpose of this article to review the careers of these Normans in Iberia in order to illustrate how the Ebro frontier began to be perceived as a legitimate theatre for the crusading movement from the earlier decades of the twelfth century, not only for Iberians, Gascon and Occitan nobles but also for northern crusaders whose traditions were very different from their southern counterparts..$^{10}$

\footnotetext{
${ }_{6}$ Emily Albu, "Antioch and the Normans", Crusading and Pilgrimage in the Norman World, Paul OldFIELD (ed.) y Kathryn HurLock (ed.), ed. Boydell, Woodbridge, 2015, pp. 159-176.

7 Derek Lomax, The Reconquest of Spain, ed. Longman, London, 1978, pp. 80-82; Kathleen Thомpson, Power and Border Lordship in Medieval France: The County of Perche, 1000-1226, ed. Royal Historical Society, London, 2002, p. 74; Lucas VILLEGAS-AristizÁBAL, "Norman and Anglo-Norman Participation in the Iberian Reconquista c. 1018-1248", PhD Thesis, University of Nottingham, Nottingham, 2007, pp. 101-145. Lucas VilLEgas-ARISTIZÁBAL, "Norman and Anglo-Norman Interventions", pp. 103-121.

8 Orderic Vitalis, Ecclesiastical History, 6, Marjorie Chibnal (trad.), ed. Oxford University Press, Oxford, 1978, pp. 402-403.

9 Lawrence Mccrank, "Norman Crusader in the Catalan Reconquest: Robert Burdet and the Principality of Tarragona", Journal of Medieval History, 7:1 (1981), pp. 62-87; BULL, Knightly Piety, pp. 258-288; Aryeh Graboïs, "The Description of Jerusalem by William of Malmesbury", Anglo-Norman Studies, 13 (1990), p. 5. 10 Carlos Laliena, "Larga stipendia et optima prædia", pp. 149-169; Lucas Villegas-Aristizábal, "Revisiting the Anglo-Norman Crusaders' Failed Attempt to Conquer Lisbon c. 1142", Portuguese Studies, 29:1 (2013), pp. 7-20.
} 
The main narrative source for both Rotrou's and Robert's involvement in Iberia is Orderic Vitalis's Ecclesiastical History, which was completed by the Norman monk a few years after the events. This chronicle has been most recently translated by Chibnal in an Oxford edition. ${ }^{11}$ Furthermore, there are some narrative Iberian sources like the fourteenth-century Chronicle of San Juan de la Peña and the sixteenth-century Los Anales de la Corona de Aragon, which are slightly less precise because of their temporal dislocation with the subject matter, but nonetheless can be used to cross reference some of the events. Also, there is a great amount of documentary evidence surviving in the archives of Spain and France which helps to confirm some of Orderic's claims as well as helping to further our understanding of these Normans' participation in the Iberian conflict. ${ }^{12}$ The Norman involvement in the Iberian wars has been studied previously by some French and Iberian historians such as Dozy, Bonnasie, Defourneux, Almaparte and Laliena as part of the French intervention in the peninsular conflict but they have not been singled out in comparison to the Norman involvement in other theatres of war in the period such as the British Isles, Sicily and the Levant. ${ }^{13}$

\section{Origins of Rotrou of Perche}

Rotrou of Perche's position as a count on the frontier of Île de France and Normandy is relatively well-documented. Also, his importance during the wars between Robert Curthose and Henry I in Normandy has made him an attractive figure to historians of the period. Kathleen Thompson has produced a full account of his Norman ventures on her work on the county of Perche. ${ }^{14}$ Rotrou was the only surviving son of Geoffrey of Montagne, viscount of Perche, and inherited the county from his father in 1099 while he took part in the First Crusade. ${ }^{15}$ Rotrou's engagement in the crusade probably occurred as a result of Robert Curthose's decision to take the cross in $1095 .{ }^{16} \mathrm{He}$ might also have been inspired by his father's involvement in the Norman conquest of England. However,

\footnotetext{
11 Orderic Vitalis, Ecclesiastical History, 6, p. 397; Nick Webber, The Evolution of the Norman Identity, ed. Boydell, Woodbridge, 2005, pp. 142-147; Emily Albu, The Normans in their Histories: Propaganda, Myth and Subversion, ed. Boydell, Oxford, 2001, pp. 180-213.

12 Lucas Villegas-AristizÁBal, "Anglo-Norman Intervention in the Conquest and Settlement of Tortosa, 1148-1180", Crusades, 8 (2009), docs. 1-19, 24.

13 BoIssonadE, "Cluny, la papauté et la première grande croisade internationale contre les sarrasins d'Espagne: Barbastro (1064-1065)", pp. 257-301; Marcelin Defourneaux, Les français en Espagne aux XIe et XIIe siècles, ed. Presses universitaires de France, Paris, 1949, pp. 145-200; LALIENA, "Larga stipendia et optima prædia", pp. 149-169;

14 Oliver de Beaune, Visconde de Romanet, Géographie du Perche et chronologie de ses comtés, suivies de pièces justificatives, formant le cartulaire de cette province, Montagne, 1902, pp. 48-51; THомPson, Power and Border Lordship, pp. 54-85; Kathleen Thомson, "The Formation of the County of Perche: The Rise and Fall of the House of Gouet", Family Trees and the Roots of Politics: The Prosopography of Britain and France from the Tenth to Twelfth Century, K.S.B. Keats Rohan (ed.), ed. Boydell, Woodbridge, 1997, pp. 299-335. 15 Jonathan Riley-Smith, The First Crusaders 1095-1131, ed. University of Cambridge Press, Cambridge, 1998, pp. 144-145.

16 Ibid.
} 
judging from his later ventures, it is likely that he had some religious inspiration for taking part in such an innovative but expensive journey. Rotrou's contribution in the First Crusade is not as well documented as those of the more famous Normans like Bohemond of Taranto, Tancred, and Robert Curthose. ${ }^{17}$ On the other hand, there are some references to his gallantry in the sieges of Nicea and Antioch..$^{18}$ In the Chanson d'Antioch and the Chronicle of William of Tyre, Rotrou is mentioned as one of the most heroic figures in the capture of Antioch and later as the commander of one of the counterattacks which dislodged the Muslim coalition forces that unsuccessfully tried to retake the city. ${ }^{19}$ It seems that Rotrou's participation in the crusade enhanced his personal prestige since he started to style himself as a count, a higher-ranking title than that of his father. ${ }^{20}$

Soon after his return from the Holy Land, according to Orderic, Rotrou was involved in an Iberian campaign against the Muslims in Aragon where he and his Norman followers attempted to help Alfonso I the Battler. Unfortunately, there is no Iberian source that corroborates Orderic's claims. ${ }^{21}$ On the other hand, a letter that survives from St Anslem of Canterbury (1103) does suggest that at least the then Bishop Diego Galmirez of Saint James of Compostela had requested aid in the war against the Muslims in the peninsula. ${ }^{22}$ Archbishop Anslem who had not been particularly eager to encourage participation in the First Crusade, was adamant that the Anglo-Norman knights were in no position to help in the struggle against the enemies of the faith. ${ }^{23}$ Although the letter requested aid for Galicia and not the Ebro Valley, it is evident that contacts did exist around the time of the mentioned expedition..$^{24}$ Therefore, the letter illustrates that soon after the successes of the First Crusade in Palestine the Iberian rulers and prelates were eager to attract foreign aid in their perceived sacred struggle against Islam.

\footnotetext{
17 Bernard S. Bachrach y David S. Bachrach, The Gesta Tancredi of Ralph of Caen: A History of the Normans on the First Crusade, ed. Rutledge, Aldershot, 2005.

18 La chanson d'Antioche, Suzanne Duparc-Quioc (ed.), ed. Librairie orientaliste Paul, Paris, 1978, lin., 2023, 2816, 2929, 3506, 3622, 4695, 6131, 8990; Guillaume De Tyr, Chronique, ed. R.B.C. Huygens, H.E. MaYer y G. Rösch, Cahiers de civilisation médiévale, Turnholt, 1986, pp. 138-139, 191-192, 329-333.

19 La chanson d'Antioche, lins. 2023, 2816, 2929, 3506, 3622, 4695, 6131, 8990; Guillaume de Tyr, Chronique, pp. 138-9, 191-2, 329-33.

20 Thompson, Power and Border Lordship, p. 52.

21 Orderic Vitalis, Ecclesiastical History, 6, p. 397.

22 "Dolet quod Angli milites contra saracenos in eius auxilium mittere non possint, cum ipsum regnum anglorum bellis commoveafur". S. Anselmi Cantuariensis archiepiscopi opera Omnia, 6, ed. Francis S. Schmitt, Thomas Nelson and Sons Press, Edinburgh, 1849, doc. 263.

23 Arish Graboïs, "Anglo-Norman England and the Holy Land", Anglo-Norman Studies, 7 (1984), p. 132; Kathryn HurLock, "Norman Influence on Crusading from England and Wales", Crusading and Pilgrimage in the Norman World, Paul Oldfield (ed.) y Kathryn Hurlock (ed.), ed. Boydell, Woodbridge, 2015, p. 73. ${ }^{24}$ Samu Niskamen, "St Anslem Views on Crusade", Medieval History Writing and Crusading Ideology, Tuomas M. S. Lehtonen (ed.), Kurt Villads JenSEN (ed.), Janne Malki (ed.) y Katja Ritari (ed.), ed. Finish Literature Society, Helsinki, 2005, pp. 67-68.
} 
Rotrou's crusading venture, according to Orderic's version of the events, ended when the Aragonese plotted against their Norman coreligionists. ${ }^{25}$ If the plot did exist and it was not a creation of Cluniac gossip against Alfonso as Nelson has suggested, it could be argued that it was a demonstration of the displeasure that the Aragonese nobility felt towards their foreign allies' involvement in their internal affairs. This sentiment was not unlike the antagonism felt by members of the Castilian and Leonese nobility against the Burgundian sons-in-law of Alfonso VI of Castile Leon. ${ }^{26}$ This is a theme that seems to have been repeated throughout the history of foreign involvement in the Iberian wars against Islam as Garcia Fitz and Novoa Portela have recently commented on their monograph. ${ }^{27}$

On the other hand, it is likely that the real justification for the short-lived venture was probably the degeneration of the situation in Normandy as Nelson argues, or perhaps Pedro I sent the Norman contingents back home without using their services for local reasons. If this expedition took place between 1104 and 1105 as Nelson has suggested, Pedro I of Aragon had a truce with the Taifa of Zaragoza. So it is likely that the arrival of an eager group of Norman crusaders did not fit with his immediate political manoeuvres. ${ }^{28}$ This is perhaps the origin of the frustration perceived by some of the crusaders who had hoped to fight in Spain but felt betrayed by the local Iberians' desire to maintain their truce with the Almoravids. If the Normans' visit took place in 1105, it might have coincided with the succession of the Navarro-Aragonese realm from Pedro I to Alfonso I, making their situation inconvenient in those circumstances. Then Alfonso I's later minor conquests of Ejea 1105 and Tamarite 1107 might have helped to increase the displeasure felt by the Normans for their inability to have a share of the spoils. ${ }^{29}$

There is an interesting similarity between Orderic's story and an episode involving an earlier Norman named Roger of Tosny who had gone to Iberia and returned as a result of the treachery of the local Iberians. ${ }^{30}$ Roger of Tosny's career in the Catalan counties was narrated briefly by Ademar of Chabannes and the Northern French Chronicle of Saint Pierre Le Vif de Sens. ${ }^{31}$ In their narratives both chroniclers explained that the Norman was involved in a series of wars against the Andalusi on behalf of the countess of Barcelona. However, they both agreed that he returned to Normandy after being

\footnotetext{
25 Lynn Nelson, "Rotrou of Perche and the Aragonese Reconquest", Traditio, 26 (1970), pp. 113-133; LALIENA, "Larga stipendia et optima prædia", p. 161.

26 Andrés Barón FARAldo, "Magnates y nobiles en la curia del conde Raimundo de Borgoña, Totius gallecie princeps (ca. 1091-1107)", Estudios mindonenses, 27 (2011), pp. 531-547.

27 Francisco García Fitz y Feliciano Novoa Portela, Cruzados en la reconquista, ed. Marcial Pons, Madrid, 2014, pp. 13-17.

28 Nelson, "Rotrou of Perche and the Aragonese Reconquest", pp. 116-117.

29 Javier ZABAlo, "Tercera Parte: Navarra", Historia de España, 6, dir. Manuel TuÑón DE LARA, Editorial Labor, Barcelona, 1980, p. 373.

30 Lucas Villegas-AristizÁBal, "Roger of Tosny's Adventures in the County of Barcelona", Nottingham Medieval Studies, 52 (2008), pp. 4-16; García Fitz y Novoa Portela, Cruzados, p. 57.

31 Georges Pons, “Adémar de Chabannes et 1'Espagne”, Aquitaine-Espagne VIIIe-XIIIe siècle, Philippe SÉnac (ed.), ed. Centre d'étudies supérieures de civilisation médiévale, Poitiers, 2001, pp. 69-82; Medieval History Writing and Crusading Ideology, Tuomas M. S. Lehtonen (ed.), Kurt Villads Jensen (ed.), Janne MalkKi (ed.) Katja Ritari (ed.), y Pascal Buresi (ed.), ed. Finnish Literature Society, Helsinki, 2005.
} 
ambushed by locals. Ademar blames the Muslims, while the Chronicle of Saint Pierre Le Vif seems to accuse the local Christians. ${ }^{32}$ In any case these actions have a certain similarity with Orderic's version of the events of Rotrou's first misadventure in Iberia. It is possible that this earlier occurrence either confused or influenced Orderic's views on the failure in this particular venture. Also, the treachery of the local Iberians was not unlike the one supposedly contrived against Roland in the famous epic poem. ${ }^{33}$ Moreover, Linehan has noted that in the twelfth century some in Frankish lands believed the tales of Charlemagne's conquest of Iberia and the hypothetical inability or treachery of the local Christians in keeping it under Christian rule. ${ }^{34}$

\section{Origins of Robert Burdet}

According to Orderic Vitalis, Robert Burdet was originally from the village of Cullei (Rabodanges) in Normandy. ${ }^{35}$ From the name used by Orderic in his chronicle, one may infer that Robert Burdet belonged to the branch of the family who stayed in Normandy after the Norman conquest of England. Nevertheless, it is also possible that he may have had Anglo-Norman connections since, as Orderic affirms, Robert's first wife Sybil was a daughter of William le Chèvre, which the PASE Domesday identifies as a landowner in Devon by $1086 .{ }^{36}$ In his edition of Orderic's chronicle, Le Prévost mentioned a link between the Burdet family in Normandy, which as Chibnal has correctly asserted, was still flourishing in the middle of the twelfth century and the branch of the same family who arrived in England soon after the Norman conquest and settled in Leicestershire. ${ }^{37}$ According to Chibnal, the Burdets were vassals of the Grandmesnils in Normandy. ${ }^{38}$

Also, if Robert Burdet was indeed from Cullei as Orderic has claimed, there was a noticeable feudal arrangement in this locality before his departure that perhaps influenced his later decision to accept the over-lordship of the church in his newly acquired frontier fiefdom. As Haskins and Chibnal have noted, the village of Cullei had been granted as a fiefdom to the Abbey of Saint-Évroult by Hugh de Grandmesnil at some point in the mid-eleventh century and the arrangement was maintained until Orderic's time..$^{39}$ More interestingly, a certain Samson of Cullei who is mentioned in several charters from the reigns of William I and Henry I seems to have kept a close connection with the Abbey

\footnotetext{
32 Villegas, "Roger of Tosny’s Adventures", pp. 7-8.

33 Peter Linehan, Spain 1157-1300, A Partible Inheritance, ed. Wiley-Blackwell, Oxford, 2008, p. 4.

34 Linehan, Spain, p. 4; Carol Sweetenham y Lind M. Paterson, The Chanson d'Antioche: An Old French Account of the First Crusade, ed. Ashgate, Aldershot, 2000.

35 Orderic Vitalis, Ecclesiastical History, 6, p. 402.

36 PASE Domesday, William 48 (William Chevre): http://domesday.pase.ac.uk/Domesday?op=5\&personkey=41297

37 Orderici Vitalis, Historiae ecclesiasticae libri tredecem, 5, Auguste Le Prevost (ed.), ed. Société de l'histoire de France, Paris, 1855, p. 8.

38 Orderic Vitalis, Ecclesiastical History, 6, p. 402. no. 2.

39 Charles Homer Haskins, Norman Institutions, ed. Oxford University Press, Oxford, 1918, p. 11; Marjorie Chibnal, "Military Service in Normandy before 1066", Studies in Late Anglo-Saxon and Anglo-Norman Military Organisation and Warfare, M. J. StrickLAnd (ed.), ed. Boydell, London, 2000, pp. 31-37.
} 
where also Orderic Vitalis was based. ${ }^{40}$ However, the exact relation between the Burdet family and the lords of Cullei is far from clear. Orderic himself does not say anything about their relation except for his claim that Robert was from this locality. Yet, it seems likely that he was related to this family in some way. Robert at least was acquainted with the feudal arrangement of his home locality with the abbey.

In the chartulary of Burton Lazars, Leicestershire, there are a series of documents relating to members of the Burdet family. ${ }^{41}$ Unfortunately, this collection does not make allusion to any specific dates or other indications that would relate them to Robert or his close relatives. There is, however, a Robert Burdet whom Crouch calls Robert I, who held fiefs in the area from Hugh de Grandmesnil. ${ }^{42}$ Robert I could be an ancestor of the Robert in question. This is probably the same Robert Burdet who is also mentioned as one of the retainers of Ivo de Grandmesnil and appears as a witness in the foundation charter of Kirby priory (1077) ${ }^{43}$ Certainly, this Robert Burdet is not the same one who went to Iberia during the 1120's. Crouch speculates that it was either one of his sons or grandsons. ${ }^{44}$

\section{Origins of Walter of Guidvilla}

Another Norman participant whose origins are more shadowy is Gualter or Walter de Guidvilla. He might have been from the region of Eure in central Normandy, not too far from Calvados, as documentary evidence in the area suggests. ${ }^{45}$ Furthermore, a certain Huge of Guidvilla appears in Domesday Book as a tenant of the Grandmesnils in Leicestershire and a family with this surname flourished in Yorkshire from the early twelfth century as shown by Greenway. ${ }^{46}$ The connections between these two and the Norman crusader are, however, far from certain. Laliena has suggested that Walter was the brother of Robert Guidvilla who had fiefdoms in Northamptonshire and York and who was a vassal of Nigel d'Aubigny. ${ }^{47}$ It is more likely, however, that Walter was a member of a branch of the family with cross-channel connections but based in Normandy, since this would more easily explain his attachment to Rotrou's expedition. If this is so, it is noticeable that as Robert Burdet's family, the Guidvillas in Normandy were also vassals of the Grandmesnils. Thus it is likely that Robert Burdet and Walter de Guidvilla were

\footnotetext{
40 Orderici Vitalis, Historiae ecclesiasticae, 5, pp. 193-194, 200-201.

41 Terry Bourne y David Marcombe eds., The Burton Lazars Cartulary: A Medieval Leicestershire Estate, ed. University of Nottingham, Nottingham, 1992, pp. 19, 21, 44-6, 67, 73.

42 William Farrer, Honors and Knights' Fees, 2, ed. Spottiswoode, Ballntyne \& co London, 1924, p. 329.

43 William Dugdale, Monasticon Anglicanum, 1, London, 1815, p. 562; David Сrouch, "Normans and Anglo-Normans: A Divided Aristocracy?", England and Normandy in the Middle Ages, David Bates (ed.) y Anne Curry (ed.), ed. Hambledon Press, London, 1994, p. 54.

44 David Crouch, The Beaumont Twins: The Roots and Branches of Power in the Twelfth Century, ed. Cambridge University Press, Cambridge, 2008, pp. 127-128.

45 Diana E. Greenway, Charters of the Honour of Mowbray, ed. Oxford University Press, Oxford, 1972, p. xxxiv note 1; LaLiena, "Larga stipendia et optima prædia", pp. 161-165.

46 Ibid.

47 Ibid.
} 
acquainted with each other in Normandy. Ivo de Grandmesnil had participated in the First Crusade, which might have given these vassals the idea of joining a crusading venture. So it is possible that their families had members who had been involved as part of their feudal obligations.$^{48}$ Ivo's infamous cowardice at the siege of Antioch might not have been a deterrent for joining the better-reputed Rotrou in his new venture. ${ }^{49}$ On the other hand, if Robert or Walter had been involved in the First Crusade as Ivo's vassals, their involvement in Iberia might have been seen as an opportunity to redeem their families' reputation from any tarnishing that they might have suffered by their association. As noted by Aird, the accusations of cowardice in the battlefield had an important repercussion on the nobles' ability to maintain their own authority. For example, Stephen of Blois had to return to the Holy Land in order to salvage his family reputation after his perceived cowardice at the Siege of Antioch. ${ }^{50}$

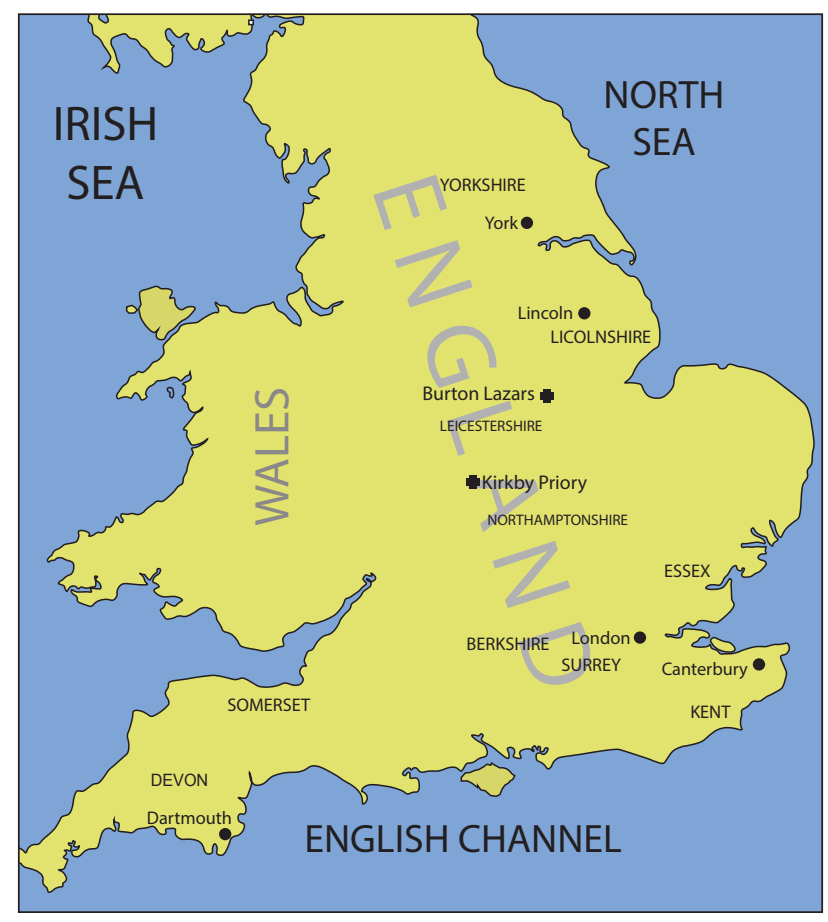

48 Jonathan Riley-Smith, "Family Traditions and Participation in the Second Crusade", The Second Crusade and the Cistercians, Michael Gervers (ed.), ed. Palgrave, New York, 1992, pp. 101-109.

49 Ivo of Grandmesnil, according to Orderic VITALIS had disgraced his family by showing cowardice and escaping the besieged city of Antioch by letting himself down some ropes from the walls of the city during the First Crusade. Orderic Vitalis, Ecclesiastical History, 5, pp. 97-99; Orderic Vitalis, Ecclesiastical History, 6, p. 19.

${ }_{50}$ William M. AIRD, “'May others, whose names I do not know fled with them': Norman Courage and Cowardice on the First Crusade", Crusading and Pilgrimage in the Norman World, Paul OldField (ed.) y Kathryn HurLock (ed.), ed. Boydell, Woodbridge, 2015, pp. 28-29. 


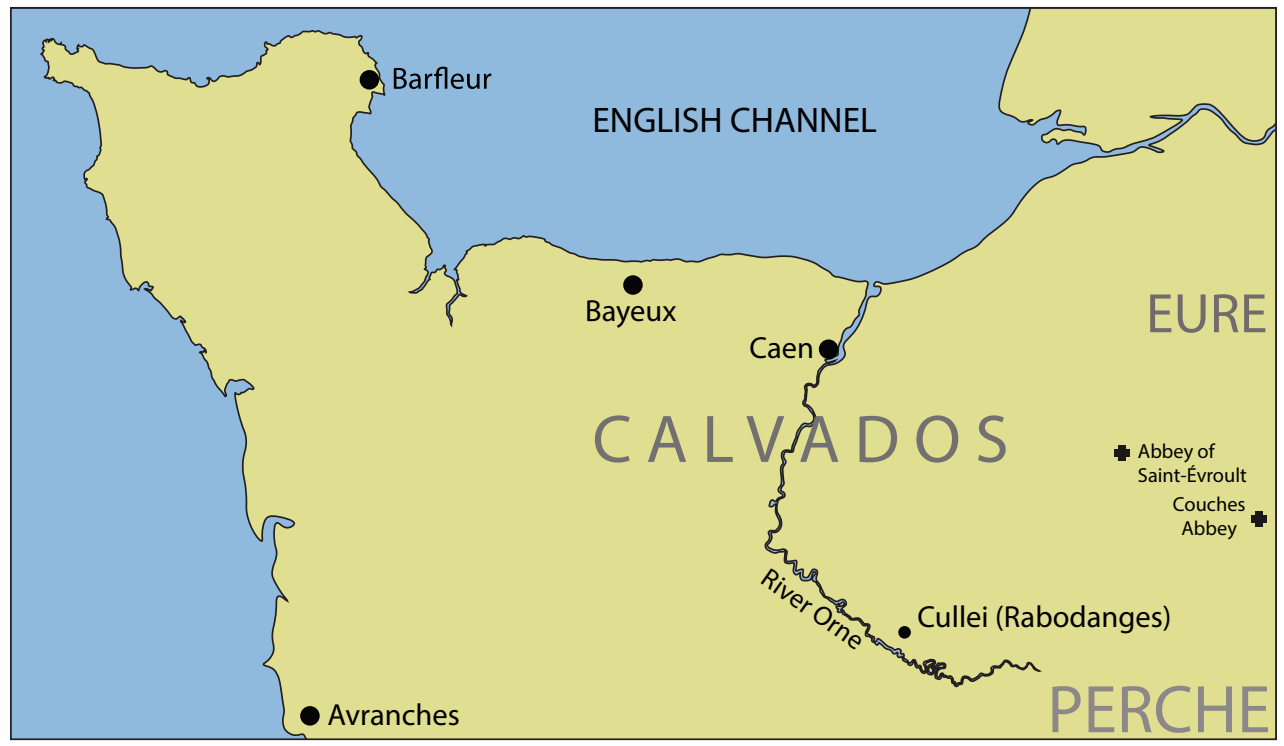

\section{The Norman tradition of involvement in Iberia}

This group was not the first northern contingent to come to Iberia to fight; there was already a flourishing tradition of Frankish influx into the peninsular campaigns by the beginning of the twelfth century. ${ }^{51}$ Some calls to aid the Iberian kingdoms and counties were made all across France to attract warriors to fight in the campaigns against the Muslims since the fall of the Caliphate of Cordoba. ${ }^{52}$ Although for most of the eleventh century the Iberian monarchs had used the church connections to encourage the involvement of the Franks in the Iberian struggle, the First Crusade to Palestine placed the institution as the main power behind the promulgation of the Iberian conflict as a legitimate theatre for those interested in gaining remission of sins by fighting the Muslims. ${ }^{53}$ Thanks to the momentum, which followed the success of the First Crusade

51 Jaime Ferreiro Alemparte, Arribadas de normandos y cruzados a las costas de la península ibérica, ed. Sociedad española de estudios medievales, Madrid, 1999, pp. 17-232; Reinhart Pieter Anne Dozy, Recherches sur l'histoire et la littérature de l'Espagne pendant le moyen âge, 2, ed. Maisonneuve \& Co., Paris, 1881, pp. 250-331; Defourneaux, Les français en Espagne aux XIe et XIIe siècles, pp. 145-200; BoIssonadE, "Cluny, la papauté et la première grande croisade internationale contre les sarrasins d'Espagne: Barbastro (1064-1065)", pp. 257-301; BULL, Knightly Piety and the Lay Response, pp. 72-80. Carlos Laliena CorberA, "Tradiciones familiares de guerra santa. Linajes aristocráticos y conquista feudal en los siglos XI y XII en Cataluña, Aragón y Castilla", Estudios en homenaje al profesor Emilio Cabrera, R. Córdoba De La Llave (ed.), J. L. Del Pino García (ed.) y M. Cabrera SÁnchez (ed.), ed. Universidad de Córdoba, Córdoba, 2015, pp. $279-292$.

52 Lomax, The Reconquest of Spain, p. 49; García Fitz y Novoa Portela, Cruzados, pp. 55-68.

53 Edward Peters (ed.), The First Crusade: "The Chronicle of Fulcher of Chartres" and Other Source Materials, ed. Penn, Philadelphia, 1998, pp. 45-46; José Goñ GazTambide, Historia de la bula de cruzada en España, ed. Europeana, Vitoria, 1958; William Purkis, Crusading Spirituality in the Holy Land and Iberia, c. 1095 - c. 1187, ed. Boydell, Woodbridge, 2008, pp. 73-76. 
to the Holy Land, more and more calls for crusading in Iberia were being made. ${ }^{54}$ The Iberian frontier would have been equally attractive as the Holy Land as a result of its proximity. So unlike the people who went to the First Crusade, the knights going to Iberia did not need much wealth to finance their journey.

\section{The clergy's desire to attract Frankish involvement}

Furthermore, Oleguer Archbishop of Tarragona and Bernard Archbishop of Toledo were keen to attract foreign soldiers to aid in the wars of conquest of Al-Andalus. ${ }^{55}$ Oleguer might have played an important role in Robert's and Rotrou's decision to go to Spain. In 1116, Oleguer, bishop of Barcelona, was elected archbishop of the still deserted see of Tarragona. ${ }^{56}$ A year later, Ramon Berenguer III, count of Barcelona, granted the lands of Tarragona to the recently-elected archbishop. ${ }^{57}$

In the grant the count did not only give the city to the metropolitan, but also encouraged the prelate to move to the urban centre..$^{58}$ The city of Tarragona was taken by the count of Barcelona in 1091, but the re-settlement of the region was not very successful. Tarragona had become almost a no-man's-land where settlers were afraid to live for fear of Andalusi raids. Since its reconquest in 1091, the bishops of Osona had held the title of archbishop, but had shown little interest in its physical restoration. ${ }^{59}$ Pope Paschal II had issued a crusading bull for the physical restoration of the see in 1116 that might have been used by the prelate to attract would-be-crusaders. ${ }^{60}$ There is some evidence that Oleguer did attempt to repopulate the area before granting it to Robert. For example, in October 1128, according to a document that exists as a copy in the chartulary of the Cathedral of Vic, he donated the Church of St Saviour located in the suburbs of the city to the bishop of Osona with its rights to gather alms. ${ }^{61}$ Moreover, Masnou has shown quite convincingly that the bishop of Osona had been engaged rather whole-hardly, onto the venture of repopulating the area in the second decade of the twelfth century with only minor success. Bishop Ramon Gaufred of Osona was so invested in to the venture that he apparently bankrupted his own diocese attempting to resettle the area in order to fence off the disputed claims of jurisdiction over the dioceses of the Hispanic March from the Archbishop of Narbonne. ${ }^{62}$ This suggests that at least there were some

\footnotetext{
54 García Fitz y Novoa Portella, Cruzados, pp. 67-74.

55 Lomax, The Reconquest of Spain, p. 61.

56 Enrique Flórez, España sagrada, 25, Madrid, 1773, pp. 116-117.

57 Ibid.

58 Ibid.

59 Lawrence MCCRANK, "The Foundation of the Confraternity of Tarragona by Archbishop Oleguer Bonestruga, 1126-1129”, Viator, 9 (1978), pp. 157-177.

60 Josep M. Masnou, "Participació del bisbe de Vic en la repoblació de Tarragona", Simpòsium: La repoblació del camp de Tarragona. Estat de la qüestió, Arxiu històric arxidiocesà de Tarragona, Tarragona, June 18, 2015.

61 Arxiu Capitular de Vic, Cal 37, LD fol. 73.

62 Masnou, "Participació del bisbe de Vic en la repoblació de Tarragona".
} 
settlers already arriving in the area at the time of Robert's appointment. On the other hand, it is not certain that many were prepared to settle permanently in the region long before that date, which might have encouraged Oleguer to go to France to the councils of Toulouse (1118) and Rheims (1119), armed with Paschal's bull, with the important mission of recruiting soldiers to help defend his newly acquired principality. ${ }^{63}$

The count of Barcelona probably hoped that by granting Tarragona, the archbishop would use his influence to repopulate the city. Ramon Berenguer III seems to have had little zeal for conquest throughout his reign with the exception of the ephemeral conquest of the Balearic Islands in $1115 .{ }^{64}$ However, in his transitory conquest of Majorca, he used Norman contingents from southern Italy, who had introduced him to the potential of the Normans as allies against the Muslims ${ }^{65}$ He might even have benefited from papal support for this expedition creating a precedence for crusading endeavours in the area ${ }^{66}$ The Norman contingents were also perhaps encouraged by Calixtus II's Lateran Council Crusading bull (1123) in which he compared the war in the east with the Iberian struggle and gave its participants the same remission of sins as those heading for Jerusalem. ${ }^{67}$ Certainly, these comparisons between the wars in the east and those in Spain were not completely alien to the peninsular clergy. Since the time of Alexander II and Gregory VII, they had received support from the papacy to encourage Frankish involvement in Spain. ${ }^{68}$ Moreover, Urban II and his successors were prepared to grant indulgences to those getting involved in the Iberian campaigns against the Muslims as he had offered to the participants of the First Crusade. Indeed, this official encouragement from the papacy helped to make the new archbishop keener to try to restore his see. Also, the precarious position of the archiepiscopal see with its depopulated territories certainly forced the new prelate to call for help on the northern side of the Pyrenees. ${ }^{69}$ This is suggested in the charter of the donation of Tarragona to Robert by Oleguer where he makes allusion to the aid supplied by Popes Galesius II and Calixtus II in securing

\footnotetext{
63 Mansi, 21, pp. 128-148; Juan Tejada y Ramiro (ed.), Colección de Cánones y de todos los concilios de la iglesia española, 3:2, ed. Imprenta de Don Pedro Montero, Madrid, 1854, p. 249; "Chronique Sancti Maxentii”, Chroniques des églises d'Anjou, Paul Marchegay (ed.) y Émile Mabile (ed.), ed. Libraire de la société de historie de France, Paris, 1869, p. 427; Damian J. Sмiтн, "The Abbot-Crusader Nicholas Breakspear in Catalonia", Adrian IV the English Pope, Brenda Bolton (ed.) y Anne J. Duggan (ed.), ed. Ashgate, Aldershot, 2003, pp. 32-33.

64 Lorenzo Veronés, La guerra de Mallorca en ocho libros, Jaume J. CAstello (trans.), ed. Bosch, Barcelona, 1996); David AbULAFIA, "The Norman Kingdom of Africa and the Norman Expeditions to Majorca and the Muslim Mediterranean", Anglo-Norman Studies, 7 (1984), pp. 26-49; García Fitz y Novoa Portella, Cruzados, pp. 79-80.

65 Ibid.

66 Carlricard BRüHL (ed.), Codex diplomaticus regni Siciliae: Roger II. Regis diplomata latina (Series 1), 2:1 ed. Köln, Würzburg, 1987, doc. 9.

67 "Omnibus enim in hac expeditione constanter militabus eamdem peccatorum remissionem, quam Orientalis Ecclesice deffensoribus facimus, apostolica auctoritate et concessa nobis divinitus potestate, benigne concedimus". Enrique Florez, España Sagrada, 25, ed. Rafael Lazcano, Madrid (dir.), 2007, p. 227.

68 Bull, Knightly Piety, p. 81.

${ }^{69}$ Lomax, The Reconquest of Spain, p. 59.
} 
the possession of Tarragona. ${ }^{70}$ Perhaps Tarragona's proximity to the well-armed and prosperous Muslim city of Tortosa dissuaded the local Catalan nobles from maintaining garrisoned castles, preferring to keep the area as a buffer zone. ${ }^{71}$

Although there is no complete record of Oleguer's intervention at Rheims, Orderic Vitalis does say that he was present and it is plausible that he addressed the council about his problems in defending his archiepiscopal see and attempted to encourage his French counterparts to assist him. ${ }^{72}$ This is something for which he might have had the support of Calixtus II, who being related to many of the most powerful people in the peninsula, was keen to promulgate the crusading movement in the area. ${ }^{73}$ It is likely that Robert Burdet, Walter de Guidvilla and the others joined Rotrou's army while in Normandy and when the latter decided to travel to Spain to fight, the rest simply followed. If Orderic's account of Rotrou's earlier expedition to the peninsula in the first decade of the twelfth century is to be believed, he knew the conditions and potential for conquering land there. ${ }^{74}$ Rotrou's earlier experience as a crusader made him keen to join this new crusading venture like his contemporary and fellow veteran of the First Crusade, Gaston de Bearn. ${ }^{75}$ The Ebro valley was rich in agricultural produce as it is today and the prospect of holding lands there would have surely attracted the attention of the Normans. ${ }^{76}$ For instance, Robert Burdet's later career suggests that he had been prepared to stay in these new territories while Rotrou, though eager to gain land, had no interest in staying. Rotrou had experience holding fiefs as an absentee landlord in England where he held his wife's dowry.

\section{Other reasons for the Norman interest in the Ebro Frontier}

Apart from these, there is also some circumstantial evidence that helps to explain Rotrou's reasoning for joining the expedition. Rotrou was Alfonso I's first cousin through their mothers and belonged to the well-connected Roucys. ${ }^{77}$ Interestingly, Count Eblous II of Roucy who was Rotrou's and Alfonso's mutual maternal uncle had contemplated a

\footnotetext{
70 Archivo de la corona de Aragón, Cancillería, Registro No. 3, fol. 6. Pub. en José M. Font Rius (ed.), Cartas de población y franquicia de Cataluña, 1, ed. CSIC, Barcelona, 1969, pp. 87-88.

71 Ramon MiRavalL, Immigració Britànica a Tortosa, ed, Editorial Rafael Dalmau, Barcelona, 1972; Antoni VIRGILI, "Angli cum multis aliis alienigenis: crusade settlers in Tortosa (second half of the twelfth century)", Journal of Medieval History, 35 (2009), pp. 297-300; VILLEGAS, "Anglo-Norman Intervention", pp. 63-64.

72 Orderic Vitalis, Ecclesiastical History, 6, p. 275.

73 Calixtus II was the paternal uncle of Alfonso VII of Castile-Leon and Afonso Henriques I of Portugal. Gerónimo Zurita y Castro, Anales de la corona de Aragón, 1, Antonio Ubieto Arteta (ed.) y Desamparados Pérez Soler (ed.), ed. Anubar, Valencia, 1972, p. 180; Richard A. Fletcher, "Reconquest and Crusade in Spain", Transactions of the Royal Historical Society, 37 (1987), p. 43.

74 Orderic Vitalis, Ecclesiastical History, 6, pp. 397-399.

75 LaLIENA, "Larga stipendia et optima praedia", pp. 151-155.

76 Joaquín VAllvé, La división territorial de la España Musulmana, ed. CSIC, Madrid, 1986, pp. 302-305.

77 Thompson, Power and Border Lordship, pp. 59-60.
} 
crusading-like expedition into Iberia at the behest of Pope Gregory VII in the 1070's. ${ }^{78}$ That this expedition did not take place would not have mattered. This earlier planned venture could have served as a prototype for later endeavours and would have helped to keep the Iberian theatre as a legitimate area for involvement from Rotrou's family's point of view. ${ }^{79}$

Moreover, Beatrix of Roucy, Rotrou's mother seems to have influenced her son with her devotion for the well-connected monastery of Cluny. ${ }^{80}$ The Cluniacs as many historians have suggested were partially responsible for the proclamation of the benefits of holy war against the enemies of Christ in Iberia. ${ }^{81}$ With their connections to the Iberian monarchs of Leon, they had acquired a substantial number of daughter religious houses in the pilgrimage route to the Shrine of St James of Compostela, one of the most revered pilgrimage sites in Europe..$^{82}$ Their special relation with the Iberian theatre might have placed them as important conduits of the idea of fighting in the western frontier for the Norman nobility and more specifically for Rotrou and his followers.

Rotrou might have had other circumstantial reasons for helping his cousin. In the White Ship tragedy King Henry I was left without a male heir ${ }^{83}$ and Rotrou lost his wife and two nephews. ${ }^{84}$ This personal tragedy might have encouraged him to go on crusade as penance for his perceived sins. ${ }^{85}$ Thompson suggests that Rotrou might also have found it politically convenient to be away from Normandy on a crusading venture as a public display of his sorrow for the loss of his wife, who after all was Henry I's daughter. ${ }^{86}$ In doing so he could avoid being drawn into the succession crisis that he perhaps anticipated in the Anglo-Norman domains.

According to the evidence, Robert acquired his position in Tarragona while he was in charge of Tudela. So when he set off for Aragon, he was not taking part because he had been directly invited by the archbishop. Instead, he might have been inspired by the success of earlier Normans, who had taken part in the Iberian wars and had been rewarded with

\footnotetext{
78 Herbert E. Cowdrey, The Cluniacs and the Gregorian Reform, ed. Clarendon Press, Oxford, 1970, p. 221; José María LaCarra De Miguel, Vida de Alfonso el batallador, ed. Guara, Zaragoza, 1971, pp. 15-17; Malcolm Barber, The Two Cities: Medieval Europe 1050-1320, ed. Routledge, London, 1993, p. 346; Lucas Villegas-AristizÁbal, "Gregory VII and Eblous II of Roucy: Proto-Crusade in Iberia", Medieval History Journal, 21:1 (2018), forthcoming.

79 Nelson, "Rotrou of Perche and the Aragonese Reconquest", pp. 130-134.

80 Thompson, Power and Border Lordship, pp. 60-62.

81 Lomax, The Reconquest of Spain, pp. 56-58; Giles Constable, "Ch. VII: Cluny and the First Crusade", in Cluny from the Tenth to the Twelfth Centuries, ed. Ashgate, Aldershot, 2000, pp. 186-187.

82 Otto K. Werckmeister, "Cluny III and the Pilgrimage to Santiago de Compostela", Gesta, 27:1/2 (1988), pp. 103-112; Theresa Martin, "Recasting the Concept of the "Pilgrimage Church": The Case of San Isidro de Leon”, La Crónica, 32:2 (2008), p. 169.

83 Judith A. Green, Henry I, King of England and Duke of Normandy, ed. Cambridge University Press, Cambridge, 2006, pp. 168-205.

84 Thompson, Power and Border Lordship, p. 71.

85 Ibid.; José Ángel Lema Pueyo, Alfonso I el batallador, ed. Trea, Guijón, 2008, p. 189.

86 Lema, Alfonso I, p. 189.
} 
the spoils of battle or fiefs under the local Iberian rulers. ${ }^{87}$ So after taking some kind of crusading vow, he might have decided to travel to Spain as part of the retinue of Rotrou, a veteran of the First Crusade. This expedition would have seemed a perfect way to gain remission of his sins and simultaneously increase his personal prestige and possessions. ${ }^{88}$ Furthermore, Orderic in his narrative of the deeds of the Normans in Iberia does say: 'Rodbertus autem cognometo Burded comes Tarracono, aliique fideles auditis rumoribus de regis impugnatione, uelociter armati laxatis habenis aduolarunt, in nomime Iesu alte uicferati sunt...et Christianorum Christi cruce signatos... ${ }^{89}$ which does suggest that he believed himself to be a crusader or at least Orderic saw him as such. This further suggests that Robert did possess some religious motivation for his venture in Iberia even though, unlike his fellow Normans, Sylvester of Saint-Calais and Reginald of Bailleul, he did not return permanently to Normandy.

In the interim, Alfonso I (the Battler) of Aragon had been trying to attract knights from across the Pyrenees, who would help increase his power to face the Almoravid threat. By 1117 the Almoravids seem to have been able to reverse most of the Christian gains for the previous hundred years and more importantly for his own political position, they had captured the economically significant city of Zaragoza. ${ }^{90}$ Although the Almoravids had been in Spain since the last decades of the eleventh century, by this time they had managed to unify almost the whole of Al-Andalus. ${ }^{91}$ The increasing power of the Almoravids over Islamic Spain helped to produce crusading fever among many of the nobles from Southern France who had originally contributed to the First Crusade. They were being called to fight for Christianity again, but this time against a threat, which was much closer to home. ${ }^{92}$ Gelasius II even promised remission of sins to those who joined the Aragonese monarch in his crusade to take Zaragoza and to fight against the Almoravid invaders who had conquered it from its native Muslim Taifa king in $1110 .{ }^{93}$ It is, however, unlikely that Rotrou took part in the conquest of Zaragoza in person, since during this time it is more likely that he was fighting with his ally and overlord Henry I of England against the Count of Flanders and the King of France..$^{94}$ According to Orderic Vitalis, in September 1119, Rotrou played a vital role in the reconciliation between his nephew Richer de l'Aquile and King Henry I. ${ }^{95}$ Rotrou also appears as the main signatory in a reconfirmation charter for the Abbey of Arcisses in Normandy

\footnotetext{
87 Alberto Ferreiro, "The Siege of Barbastro, 1064-65: A Reassessment", Journal of Medieval History, 9:1 (1983), pp. 129-144; Villegas, "Roger of Tosny's Adventures”, pp. 6-15.

88 Bull, Knightly Piety and the Lay Response, p. 113.

89 Orderic Vitalis, Ecclesiastical History, 6, p. 410.

90 Joseph O'Callaghan, Reconquest and Crusade in Medieval Iberia, ed. Penn, Philadelphia, 2003, pp. 36-38.

91 Richard Fletcher, Moorish Spain, ed. University of California Press, London, 2004, pp. 105-107.

92 Defourneaux, Les français en Espagne, pp. 156-157; Clay Stalls, Possessing the Land: Aragon's Expansion into Islam's Ebro Frontier Under Alfonso the Battler, 1105-1134, ed. Brill, Laiden, 1995, p. 37.

93 Patrologia Latina, 163, col. 507 no. 110, col. 508.

94 Green, Henry I, pp. 138-139.

95 Orderic Vitalis, Ecclesiastical History, 6, p. 250.
} 
in $1120 .{ }^{96}$ However, since Rotrou did receive some sectors of Zaragoza some years after its conquest, he might have contributed in some way. Perhaps Robert and others might have been sent in Rotrou's name to get involved in this campaign. However, in the earliest fueros of the city, neither Rotrou nor any other recognisable Norman is mentioned among the witnesses, while Gascons and nobles of the Midi are. ${ }^{97}$

Thompson suggests that another Norman, Reginald Bailleul sheriff of Shropshire, might have been involved after a dispute with Henry I in Normandy in $1119 .{ }^{98}$ However, there is no surviving Aragonese document that could confirm her theory. There is a document that Lacarra dated 1121, in which a certain Fobert appears as witness in Zaragoza. ${ }^{99}$ This document only survives as a copy, so it is difficult to ascertain if this was a copying mistake. Also, the surname is not given, so it is impossible to know for certain whether Robert arrived in Aragon at an earlier date.

The fall of Zaragoza in 1118 and Tudela in 1119 to the Christian armies under Alfonso the Battler would have been encouraging for knights hoping to gain fortune. Also, the great Christian victory at Calamocha in June 1120 where Duke William IX of Aquitaine helped the forces of the Aragonese monarch defeat the armies gathered by the Almoravids to conquer the Ebro valley, might have inspired further contributions from the Norman nobility. ${ }^{100}$ This victory certainly improved the reputation of Duke William IX of Aquitaine who had taken part in the ill-fated crusade of 1101 to the Holy Land. ${ }^{101}$ William's achievement in Iberia would have been known across the Frankish lands. ${ }^{102}$ The reference to the great loot would have encouraged Rotrou's already pious disposition for the financial benefits of such a venture. Rotrou and his Norman and Frankish followers may have arrived around 1123, or perhaps a year or two earlier for the Aragonese campaigns in the valley of the Ebro against Zaragoza and Tudela, but more likely in the campaign against Lleida. ${ }^{103}$ However, there is no mention of them in any of the contemporary sources referring to Alfonso I's campaign in Andalusia. Even Orderic, who was keen to exaggerate and give examples of Norman exploits, does not confirm their participation in these expeditions. Although Rotrou is mentioned in the Chronicle of San Juan de La Peña and later by Zurita as the person responsible for the conquest of Tudela, Nelson has shown this to be inaccurate since the city fell in 1119. ${ }^{104}$ Also, Rotrou does not appear in the earliest Christian documents of Tudela.

\footnotetext{
96 Lucien Merlet, (ed.), Cartulaire de l'abbaye de la Sainte-Trinité de Tiron, 1, ed. Imprimerie Garnier, Paris, 1883, pp. 53-55.

97 Tomás MuÑoz y Romero (ed.), Colección de fueros municipales y cartas pueblas 1, ed. Imprenta Don J. M. Alonso, Madrid, 1847, pp. 448-450.

98 Thompson, Power and Border Lordship, p. 74.

99 Villegas, “Anglo-Norman Intervention", doc. 4.

100 LACARra, Vida de Alfonso el batallador, p. 69.

101 Orderic Vitalis, "The Crusade of 1101", Chronicles of the Crusades, ed. Elizabeth Hallam Bromley Books, Godalming, 1997, p. 97.

102 La Chronique de Saint-Maixent, ed. Jean Verdon, Société d'édition les belles lettres, Paris, 1979, pp. 189-190; García Fitz y Novoa Portella, Cruzados, p. 78.

103 Villegas, "Anglo-Norman Intervention", doc. 6.

104 Nelson, "Rotrou of Perche and the Aragonese Reconquest", pp. 121-123.
} 


\section{The Normans' material rewards}

In surviving records, Rotrou is first mentioned in a twelfth-century copy of a charter dated $1121 .^{105}$ In this document he appears as a signatory witness to a donation by Alfonso I to Prior Bernard of the church of Saint Mary in Tudela. The dating of this charter has been brought into question in the latest edition by Lema who believes that it was not earlier than 1124 or $25 .^{106}$ The first undisputed mention of the Norman contingents occurs in April 1123. ${ }^{107}$ Although in this charter Rotrou is named as Comes Retro in Tudela, Robert is not mentioned as Alcaite. He is just named as one of the witnesses. ${ }^{108}$ This suggests that Robert was not appointed to the post at the same time as Rotrou was granted the city by Alfonso. In this charter Rotrou gave some houses in Zaragoza to a certain Sabino, one of his retainers, for his services. ${ }^{109}$ Although this grant does not mention Robert as a milite, it does seem to confirm through the list of witnesses that Robert was part of Rotrou's retinue together with others who also seem to be from France including Elrich d'Orleans and Walter de Gaul. ${ }^{110}$ Even though this charter is the first one to confirm Rotrou's arrival, it suggests that he had gained possession of the city perhaps in 1122. Sabino's origins are far from certain since his surname is not mentioned, but it is likely that he was also from Northern French birth.

Furthermore, in a document which is dated October 1124, Rotrou also appears, without Robert being mentioned, as witness to a donation by Alfonso to one of his vassals in Zaragoza. ${ }^{111}$ Subsequently, Robert is first mentioned as alcaite of Tudela in a charter dated April 22, 1125 which states in its final lines: 'Equitaniensis comitis nomine Retrot, sub iussu Adefonsi imperatoris est dominator Tutele. De manu comitis est alcaite in Tutela Rotbert Bordet, et iusticia Duran Pexon'. ${ }^{112}$ This charter confirms Robert's position as ruler of Tudela and as Rotrou's representative, who is in turn acknowledged as vassal of Alfonso I who still holds his title of Emperor from his marriage to Urraca of Castile-Leon. Orderic Vitalis informs us that Rotrou led an army made up of Franks and Gascons against a fortress named Peña Cadiella (Benicadell). ${ }^{113}$ Although this expedition is not recorded in any contemporary Iberian source, it is likely that as Lacarra and more recently Lema

\footnotetext{
105 José María Lacarra de Miguel (ed.), Documentos para el estudio de la reconquista y la repoblación del valle del Ebro, ed. Anubar, Zaragoza, 1982, doc. 80.

106 José Ángel Lema Pueyo, Colección diplomática de Alfonso I de Aragón, ed. Euskoa, San Sebastián, 1990, doc. 161 , nota *

107 Villegas, “Anglo-Norman Intervention”, doc. 6; Stalls, Possessing the Land, pp. 127-128.

108 Arxiu de la Catedral de Tarragona, Perg. Núm. 4; José María LACARra DE Miguel (ed.), "Documentos para el estudio de la reconquista del valle del Ebro", Estudios de la edad media de la corona de Aragón, 3, ed. CSIC, Zaragoza, 1948, doc. 125.

109 Archivo del Pilar, Arm. 9, caja 1, leg. 2, n. 4; Villegas, “Anglo-Norman Intervention”, doc. 7.

110 Ibid.

111 Archivo del Pilar, Arm. 1, caja 9, leg. 1, n. 6; Luis Rubio, Los documentos del Pilar: Siglo XII, ed. Fernando el Católico, Zaragoza, 1971, pp. 11-12.

112 Archivo de la Catedral de Tudela, Perg. Núm. 4; Lacarra (ed.), "Documentos para el estudio de la reconquista del valle del Ebro", doc. 125.

113 Orderic Vitalis, Ecclesiastical History, 6, p. 401; Lema, Alfonso I, pp. 189-192.
} 
have pointed out it was launched against a hill protecting a passage between Valencia and Alicante. Its strategic importance was obvious enough to have been planned by Alfonso himself as a preamble to his great venture against Al-Andalus the following year. ${ }^{114}$ Lacarra dated the raid to the winter of 1124 and 1125 . According to documentary evidence quoted by Lacarra, Galindo Sanchez, the leader of the confraternity of Balchite, who Orderic names simply as Galindo, was back in Aragon in spring 1125. ${ }^{115}$ Galindo seems to have gained a great standing among his comrades since Orderic applauses his valour defending the fortress against a counter-offensive. ${ }^{116}$

Orderic claims that Rotrou returned to his domains with most of his retinue on 1125 and therefore, he was not involved in Alfonso's expedition in Andalusia. Orderic says that Alfonso's reason for this venture was partly out of envy for Rotrou's successes. ${ }^{117}$ Orderic Vitalis's source of information was probably gathered from eyewitnesses. Nelson has suggested that these may have been Sylvester of Saint-Calais and Reginald of Ballieul-en-Gouffren, for Orderic mentions these two relatively unimportant noble participants. ${ }^{118}$ Misunderstandings of these two may have coloured and helped Orderic to over-emphasise the importance of Rotrou's achievements in comparison to those of the Aragonese monarch. Sylvester's position in Uncastillo is noted in a document dated March 1125, confirming his involvement in Iberia. ${ }^{119}$

In a charter dated February 28, 1126, Rotrou is established in possession of the Castle of Tudela. ${ }^{120}$ Interestingly, towards the end of this text the scribe states that: "tempore quo rex Adefonsus erat in host in Tudela trouis agonese multa gente pagana". ${ }^{121}$ It seems Robert had been left in situ at Tudela's castle. It is, therefore, possible to infer that he was somehow considered trustworthy enough by both Rotrou and Alfonso to be left in charge of this vulnerable frontier town. This document also helps to confirm Orderic's claim that Rotrou was back in Normandy. Similarly to his fellow Norman Guy de Fresnel, who had been left in charge of the strategic frontier castle of Harim in the borderlands of Antioch by Tancred of Houteville in the aftermath of the First Crusade, Robert's desire for extra loot from an expedition as promising as Alfonso's raid of Al-Andalus was outweighed by his feudal and crusader obligations in defence of the city. ${ }^{122}$ Perhaps his trustworthiness made him more appealing as a candidate for the protection of Tarragona.

\footnotetext{
114 Ibid.

115 Orderic Vitalis, Ecclesiastical History, 6, p. 400.

116 Ibid.

117 Defourneaux, Les français en Espagne, p. 162.

118 Nelson, "Rotrou of Perche", p. 132.

119 Lema, Colección diplomática, doc. 149.

120 "Sub ec comité Rotró in Tutela, sub quo Robert Bordet in castello". Archivo de la catedral de Calahorra, Número 17; LacARra, "Documentos para el estudio de la reconquista", doc. 129.

121 Archivo de la Catedral de Calahorra, doc. núm. 17.

122 Lacarra, Alfonso, pp. 83-7; García Fitz and Novoa Portella, Cruzados, p. 78; Stalls, Possessing the Land, p. 51; Andrew Buck, "The Castle and Lordship of Hārim and the Frankish-Muslim Frontier of Northern Syria in the Twelfth Century", Al-Masāq, 28:2 (2016), p. 115.
} 
In a charter published by Muñoz y Romero dated 1127, Alfonso the Battler gives the fueros to Tudela and its neighbours, mentioning as usual both Rotrou and Robert. ${ }^{123}$ In this charter Robert's position as alcaite suggests that he was in charge of the castle and perhaps the defence of the city. The document explains as follow: 'Robert Bordet alchaite in illo castello de Tudela' ${ }^{124}$ Duran Pixon, as in earlier charters, is mentioned as justice. Walter de Guidvilla is also mentioned in possession of the locality of Borota (Bureta). This shows how Rotrou's less well known followers were also rewarded with lands and possessions in Aragon. In Walter's case he is cited in further six charters dating from 1127 to 1131 possessing lands and as a guarantor of royal donations. ${ }^{125}$ His rank seems to have grown enough to be considered as one of the witnesses of the fueros of Zaragoza, Tudela, and Araciel. ${ }^{126}$

\section{Rotrou's return}

Furthermore, it seems that by December 1128, Rotrou was back in Iberia since in a document dated then (which only exists in a sixteenth-century copy), he was granted the town and Castle of Corella by Alfonso, therefore making it unlikely that he was absent at the time. ${ }^{127}$ Lema has pointed out that the donation was given as recompense for services provided by the Norman to the Aragonese monarch. However, this is not clear in the charter especially regarding the fact that Rotrou had not been in Iberia for three years. ${ }^{128}$ Also, in the fueros granted to the Frankish settlers of the town of San Saturino of Pamplona dated September 1129, Rotrou appears as a witness. ${ }^{129}$ Of course it was in 1129, when Robert received the city and the area of Tarragona as an ecclesiastical fiefdom.

The last document in which Robert and Rotrou are mentioned in possession of Tudela is dated November $1131 .{ }^{130}$ By the latter date, however, Robert was already prince of Tarragona and was more likely living in the Catalan city or travelling back and fourth. ${ }^{131}$ The fact that Rotrou is mentioned as a vassal of Alfonso in all the charters also seems to confirm Nelson's theory that Rotrou did not hold the town under complete autonomy from Alfonso, as it is claimed in the fourteenth-century Chronicle of San Juan de la

\footnotetext{
${ }^{123}$ Muños, Colección de fueros municipales, 1, pp. 420-422.

124 Ibid.

${ }_{125}$ Archivo Municipal de Tudela, Caj. I, n. 2; Archivo General de Navarra, Comptos, caj. I, n. 15 IV; Archivo General de Navarra, Cartulario Real III, 203; Archivo Histórico Nacional, códices, cartulario del Temple, 595 B, fol. 1r; Archivo Municipal de Zaragoza, R.2; Archivo General de Navarra, códices, Cartulario Real IV, fol. 18v.-19r; Archivo de la Catedral de Tudela, Conejares, Instrumentos, T. III, fol. 45; Archivo de la Seo de Zaragoza, Cartulario pequeño, fol. 50.

126 Ibid.

127 Archivo Municipal de Corella, Privilegios, Leg. 1, fol. 14 (perdido); Archivo General de Navarra, Comptos, caj. I, n. 15 IV; Florencio IdoAte, Catálogo documental de la ciudad de Corella, ed. Institución príncipe de Viana, Pamplona, 1964, doc. 1.

${ }^{128}$ Lema, Alfonso I, p. 228.

129 Ibid.

130 Archivo de la Catedral de Tudela, número 1059 A and 1060 B; LACARRA, "Documentos para el estudio de la reconquista", doc. 165 .

131 Ibid. docs. 125, 129, 165.
} 
Peña. ${ }^{132}$ Rotrou keeps appearing as lord of Tudela until 1134. With the death of Alfonso, the count of Perche seems to have finally decided to quit his Iberian entanglements and return home to Normandy.

\section{Robert Burdet and Tarragona}

The granting of property, special rights and freedoms was intended to attract settlers from the older and more secure Christian territories to the newly-conquered cities and lands on the frontiers of Christendom. ${ }^{133}$ Although the evidence suggests that Robert had little to do with the running of the government of Tudela apart from being a witness in all the charters, he may have learned Iberian ways for resettling. ${ }^{134}$ In addition, the charters suggest that Robert was close to Rotrou of Perche, being given the charge of this important outpost. ${ }^{135}$

Oleguer's reasons for choosing Robert as prince of Tarragona are hard to pinpoint with great certainty. It is likely that he preferred to choose a foreign knight over a local Catalan to avoid raising local disputes. The Iberian cleric might have come to the conclusion on the other hand that a landless Norman knight would be more easily controlled since he did not have an important power-base nearby. Canon Blanch in his Arxiepiscopologi claims that Oleguer chose Robert on the recommendation of his suffragan in Osona. ${ }^{136}$ The bishop of Vic as it has been noted did possess the Church of Saint Saviour in the outskirts of Tarragona, so he was obviously interested in the establishment of some security in the area. ${ }^{137}$

McCrank suggests in his article that Oleguer might have met Robert when he was in Aragon c. 1122, confirming Alfonso's short-lived Military Order of Balchite. ${ }^{138}$ However, the historical record does not confirm beyond doubt that Robert was in Aragon by that date. It is more likely that Ramon Berenguer III or Alfonso I or one of their vassals suggested Rotrou for the post of prince of the city. Additionally, Rotrou in turn might have recommended his lieutenant instead for the post, since he was probably planning to return to his county of Perche. Alfonso I was certainly acquainted with the Norman as the charters of Tudela imply. ${ }^{139}$ Moreover, the count of Barcelona might have met Robert when Alfonso I unsuccessfully tried to conquer Lleida. Alfonso's attempt to take the city started in February 1123 and it is known that by April, Robert and Rotrou were already in possession of Tudela.

\footnotetext{
132 NeLson, "Rotrou of Perche", pp. 121-126.

133 Angus MacKay, Spain in the Middle Ages, ed. St Martin's Press, London, 1977, pp. 36-45; LemA, Alfonso I, pp. 227-229.

134 Lacarra, "Documentos para el estudio de la reconquista", docs. 125, 129, 165; Stalls, Possessing the Land, pp. 64-79.

135 MCCRANK, "Norman Crusaders in the Catalan Reconquest", p. 69.

136 Joseph Blanch, Arxiepiscopologi de la santa església metropolitana i primada de Tarragona, 1, ed. Diputació de Tarragona, Tarragona, 1985, p. 82.

137 Arxiu Capitular de Vic, Cal. 37, LD fol. 73.

138 McCranK, "Norman Crusaders in the Catalan Reconquest", p. 69.

139 LACARrA, "Documentos para el estudio de la reconquista", docs. 125, 129, 165.
} 
Robert's appointment as prince of Tarragona by Archbishop Oleguer in 1129 was confirmed by a charter which gave him the title and secular powers to rule the city. This charter survives in a fourteenth-century copy at the archive of the Crown of Aragon in Barcelona. This document makes reference to the donation in which Count Ramon Berenguer III had given Archbishop Oleguer full sovereignty. ${ }^{140}$ More importantly, it claims that this donation had been accepted and ratified by the papacy, which suggests that the territory of Tarragona had become a part of the patrimony of St Peter, reviving Gregory VII's claims of over-lordship of the conquered lands of Iberia. ${ }^{141}$

\section{The title of "Prince"}

In the charter which echoes the conditions of a coronation, the archbishop conferred on Robert the title of prince under his suzerainty and the consent of the count of Barcelona. Although the charter does not give any clear indication of any power relationship between the Norman prince and the count of Barcelona, it does confirm that the land had originally been granted by the latter. This acknowledgement left open the possibility that he might still have some rights over the territory. ${ }^{122}$ There is a section which also emphasises Robert's responsibility as protector of the metropolitan centre. Perhaps Robert's role as alcaite in Tudela was what Oleguer intended while giving him a more grand title to entice the Norman to stay in the more exposed frontier town. The prelate was also emphasising the position of the new prince and making it clear that ultimate sovereign power over the principality would still rest with himself.

Giving all the secular powers over land in the principality, the archbishop guaranteed Robert and his heirs' rights over the city, its people, lands, villages, mountains and sea. Moreover, the document gave Robert the responsibility of upholding the laws as well as legislating in accordance to local customs. It also maintains that all the laws would be enacted and have to be agreed by both the archbishop and the prince. ${ }^{143}$ The document certainly gave the Norman prince the ability to introduce some of his own Norman customs. There is, however, no sign that he did. Yet in 1149 his legislative powers were limited by Archbishop Bernard Tort who brought Tarragona under the same legal framework as the county of Barcelona. This may suggest that Robert introduced laws that were disliked by the count while the Tarragonese see had remained vacant after the death of Oleguer in 1137.

\footnotetext{
${ }^{140}$ Archivo de la Corona de Aragón, Cancillería, Reg. 3, fol. 6; Font Rius, Cartas de población y franquicia de Cataluña, 1, doc. 51.

141 Antoni Jordà Fernández, "Terminologia jurídica i dret comú a propòsit de Robert Bordet prínceps de Tarragona", El Temps sota control. Homenatge F. Xavier Ricomà Vendrell, ed. Diputació de Tarragona, Tarragona, 1997, pp. 358-360; Erich CASPAR, Das register Gregors VII, ed. Weidmann, Berlin, 1923, pp. 8-12; Ephraim Emerton, The Correspondence of Pope Gregory VII, ed. Columbia University Press, New York, 1990, pp. 4-7; Herbert E. J. CowDREY (trans.), The Register of Pope Gregory VII, ed. Oxford University Press, Oxford, 2002, pp. 5-9.

142 Ibid; Blanch, Arxiepiscopologi de Tarragona, pp. 82-83.

143 JORDẢ, "Terminologia jurídica i dret comú", pp. 358-360.
} 
Archbishop Oleguer kept complete control over all the ecclesiastical institutions, lands and rights. ${ }^{144}$ Robert guaranteed the freedom of the clergy and their families from any secular persecution. ${ }^{145}$ This section was intended to pledge the autonomy of the church within the state, in accordance with the Cluniac beliefs of church independence, which were by the early twelfth century firmly established in Catalonia. It was also logical for Oleguer to put these conditions in place from the beginning of the foundation of the state since this was a common area of dispute between the secular and ecclesiastical authorities as part of the rising power of the Church in the aftermath of the Gregorian reform.

The title of princeps (prince) given to Robert by the archbishop is unusual in a Catalan context of the early twelfth century (although not in other parts of western Europe), but according to Jordà Fernández it is a good example of the introduction of Roman Justinian law into Catalonia. ${ }^{146}$ It was probably intended to emphasise the fact that the new secular protector of Tarragona was a vassal of Rome and therefore under the jurisprudence of the Pope as inheritor of the power of the emperors, a claim that had been used by Popes with regards to Iberia since the pontificate of Gregory VII. ${ }^{147}$ If this is the case, it certainly shows an early adoption of Roman concepts in the legal framework of Catalonia. ${ }^{148}$ Although the title is used throughout Robert's rule over Tarragona in the latter years of his life, he also appears as comes probably as the count of Barcelona started to reclaim his over-lordship over the city. Moreover, in 1137 the new count of Barcelona, Ramon Berenguer IV, started to use the title of Prince in Aragon as part of his marriage alliance with Queen Patronilla, daughter of Ramiro II of that kingdom. The union of the two most powerful realms of eastern Iberia certainly placed more pressure on the independence of the Norman principality. ${ }^{149}$

According to Orderic Vitalis, after receiving the new fiefdom, Robert travelled to Rome to get a confirmation and to convince Pope Honorius II to free him of any secular overlordship which might have been suggested under Oleguer's donation. Then he went on to Normandy to raise some of his countrymen to help him guard his new city from the Muslim threat, while he left his valiant wife Sybil to defend the city. ${ }^{150}$ According to Flórez and subsequent historians, this trip must have taken place in 1129, soon after

\footnotetext{
144 Archivo de la Corona de Aragón, Cancillería, Reg. No. 3, fol. 6; Font ed., Cartas de población, doc. 88.

145 Eloy Benito Ruano, "El principado de Tarragona", Miscel-lània Ramon d'Abadal: estudis universitaris catalans, ed. Estudis universitàries catalans, Barcelona, 1994, p. 110.

146 JORDȦ, "Terminologia jurídica i dret comú", p. 357.

147 Caspar, Das Register Gregors VII, pp. 8-12; Emerton, The Correspondence of Pope Gregory VII, pp. 4-7; Cowdrey, The Register of Pope Gregory VII, pp. 5-9; Herbert E. J. Cowdrey, The Cluniacs and the Gregorian Reform, ed. Clarendon Press, Oxford, 1970, p. 221; Peter Linehan, History and the Historians of Medieval Spain, ed. Clarendon Press, Oxford, 1993, p. 173.

148 JORDÀ, "Terminologia jurídica i dret comú", p. 357.

149 José Ángel Sesma MuÑoz, "De la muerte de el batallador a la llegada de el primer rey de la corona de Aragón", Historia de España Menéndez Pidal: La reconquista y el proceso de diferenciación política, 9, Miguel Ángel Ladero Quesada (dir.), ed. Espasa, Madrid, 1998, pp. 678-679.

150 Orderic Vitalis, Ecclesiastical History, 6, pp. 404-405.
} 
the Norman knight had accepted the donation. ${ }^{151}$ Sybil seems to exemplify the wives of crusaders who went to the Holy Land, keeping charge of their husband's lands and properties in their absence. However, in Sybil's case, it seems that the roles were reversed since she stayed in the conquered land defending their new territories while her husband returned to his homeland to recruit followers. ${ }^{152}$

Orderic is the only source for Robert's visit to Rome and Normandy, therefore it is difficult to corroborate his claims. However, there are no charters from 1130, in which he appears as witness which could indicate his absence. Orderic was probably completing his chronicle around the time when Robert visited Normandy, which perhaps indicates that the Norman adventurer was one of the sources for his narrative. On the other hand, Orderic does not tell us how successful Robert's mission was. It is likely that Robert might have convinced several knights since he was able to aid Alfonso I the Battler in his campaign against Fraga (1135). ${ }^{153}$ Also, Robert managed to protect the city until there were enough settlers in the area. The exact number of participants is uncertain due to the lack of documentary evidence from the period between 1129-1146. ${ }^{154}$ However, there are a number of donations, which according to Blanch, were made by Robert and his second wife Agnes to several settlers of unknown origin. ${ }^{155}$

\section{Conclusion}

The Norman involvement in the Ebro frontier in the first half of the twelfth century shows how this theatre began to attract a number of crusaders from various areas of Europe, soon after the successes in the East. The Normans and their Anglo-Norman successors in England by the 1140's were not only acquainted with the Iberian struggle but were actively being encouraged to participate with promises of both temporal and sacred rewards. It is noticeable that in the two sieges of Lisbon $1142^{156}$ and $1147^{157}$ as well as that of Tortosa $1148^{158}$ many Anglo-Normans were involved. It is unlikely that they were unaware of the achievements of Rotrou and his followers two decades earlier. Therefore, these earlier groups of Normans helped make the Iberian frontier a legitimate area in the rapid development of the crusading theology of the first half of the

\footnotetext{
151 FlóRez, España sagrada, 25, p. 126; MCCRANK, "Norman Crusaders in the Catalan Reconquest", p. 69.

152 Joaquim Miret i SANS, "La familia de Robert Burdet", Segundo congreso de historia de la corona de Aragón: Actas y memorias, 1, ed. Talleres Tip. de J. Martínez, Huesca, 1922, p. 54.

153 Orderic Vitalis, Ecclesiastical History, 6, p. 410.

154 McCrank, "Norman Crusaders in the Catalan Reconquest", p. 70.

155 Blanch, Arxiepiscopologi, pp. 82-85.

156 VILLEGAS, "Revisiting the Anglo-Norman Crusaders", pp. 7-20.

157 Nicholas JASPERT, "Capta est Dertosa clavis christanorum: Tortosa and the Crusades", in. The Second Crusade: Scope and Consequences, ed. Jonathan PHiLlips y Martin Hосн, Manchester University Press, Manchester, 2001, pp. 90-110; Maria João Branco, "A conquista de Lisboa revisitada", Arqueologia Medieval, 7 (2001), pp. 217-234; García y Portela, Cruzados, pp. 105-114.

158 Sмiтн, "The Abbot-Crusader Nicholas Breakspear", pp. 32-33; Villegas, "Anglo-Norman Intervention", pp. 63-129; VIRGILI, "Angli cum multis aliis alienigenis", pp. 297-312.
} 
twelfth century. ${ }^{159}$ The acquisition of lands for permanent settlement by Robert Burdet and Walter de Guidvilla also showed successive waves of crusaders about the potential for material rewards in the Iberian frontier. On the other hand, Rotrou and his followers were the last group of Norman crusaders to travel to Iberia through the land route. With the rise of the Latin States, it seems that most Norman and Anglo-Norman crusaders who participated in the Iberian conflict from 1142 onwards did so by sea, shifting to a certain degree their interest towards the western side of the peninsula. However, this did not stop them from getting involved in the Iberian Levant as was the case of the crusade of Tortosa 1148 and perhaps the thirteen-century conquest of Valencia.

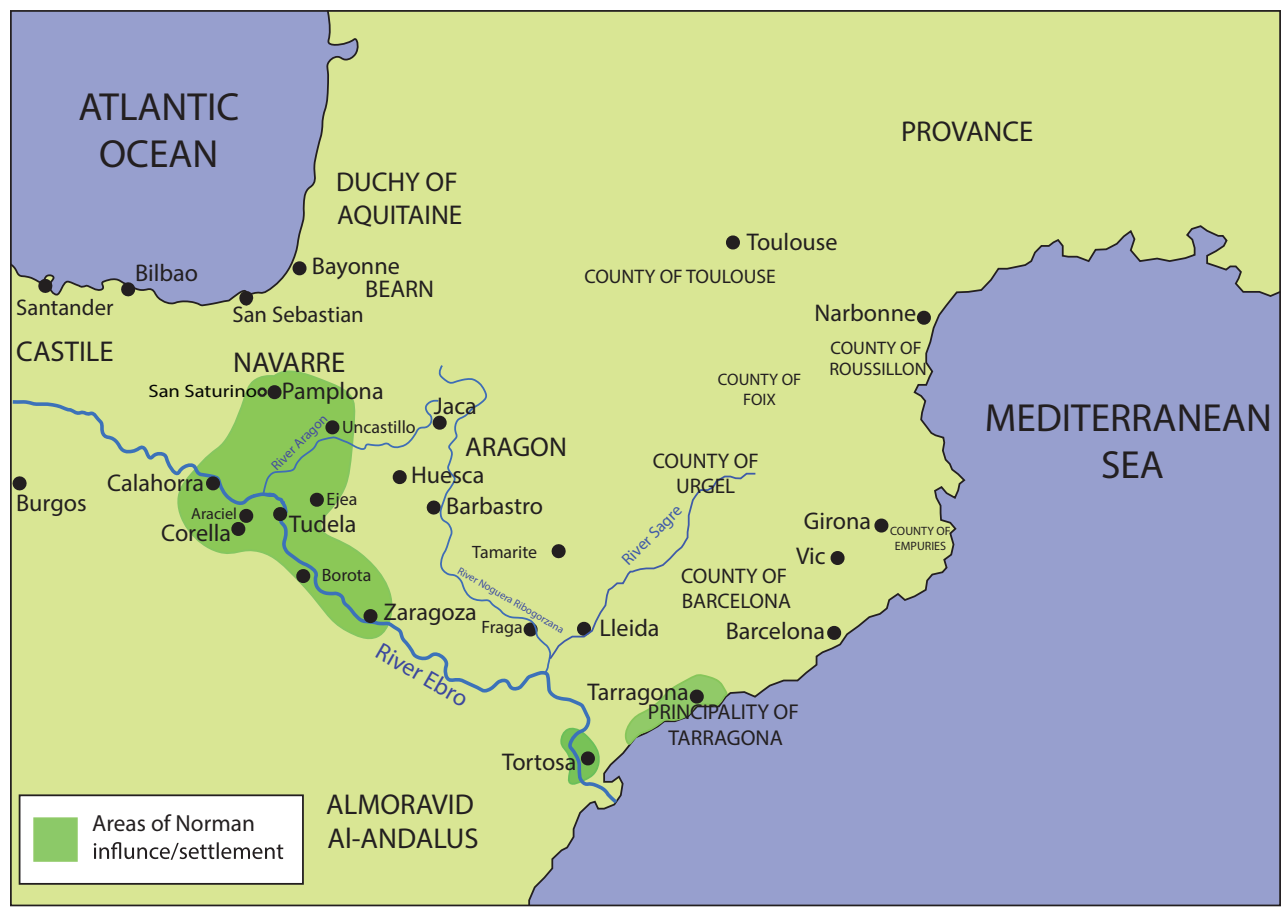

Fecha de recepción: 18 de agosto de 2016

Fecha de aceptación: 22 de noviembre de 2016

159 VILlegas, "Norman and Anglo-Norman Interventions in the Iberian Wars", pp. 108-111. 